\title{
PENGARUH SUPLEMENTASI PROBIOTIK ISI RUMEN KERBAU DENGAN LEVEL BERBEDA TERHADAP NILAI KECERNAAN DAN TDN PADA DOMBA BALIBUL
}

\author{
EFFECT OF DIFFERENT LEVEL OF BUFFALO RUMEN CONTENT AS PROBIOTIC \\ ON DIGESTIBILITY AND TDN OF BALIBUL LAMBS
}

\author{
Sutrisno*, Surono* dan Kamilia Afliha \\ Laboratorium Ilmu Nutrisi dan Pakan Fakultas Peternakan dan Pertanian Universitas \\ Diponegoro, Semarang. \\ J1. Prof. H. Soedarto, S.H - Tembalang Semarang, Indonesia 50275 \\ *Email: sutrisno63@gmail.com \\ Diterima: 7 Nopember 2020, Direvisi: 237 Nopember 2020, Disetujui: 4 Desember 2020
}

\begin{abstract}
ABSTRAK
Penelitian ini bertujuan untuk mengkaji kecernaan bahan kering (KcBK), kecernaan bahan organik (KcBO) dan total digestible nutrients (TDN) pada domba balibul yang mendapat pakan komplit yang disuplementasi probiotik isi rumen kerbau dengan level berbeda. Materi yang digunakan adalah domba ekor tipis (DET) jantan berumur di bawah 5 bulan (balibul) dengan bobot badan awal rerata 11,52 $\pm 0,78 \mathrm{~kg}$ sebanyak 16 ekor. Penelitian menggunakan rancangan acak lengkap (RAL) yang terdiri dari 4 perlakuan dan 4 ulangan. Perlakuan yang diterapkan adalah T0 (pakan komplit dan tanpa probiotik isi rumen kerbau), T1 (pakan komplit dengan 5\% isi rumen kerbau), T2 (pakan komplit dengan 10\% isi rumen kerbau) dan T3 (pakan komplit dengan 15\% isi rumen kerbau). Parameter yang diamati yaitu KcBK, KcBO dan TDN. Hasil penelitian menunjukkan bahwa pemberian pakan perlakuan yang mengandung level probiotik berbeda tidak berpengaruh nyata terhadap $\mathrm{KcBK}$ dan $\mathrm{KcBO}$ pada domba $(\mathrm{P}>0,05)$, tetapi berpengaruh nyata terhadap nilai TDN domba $(\mathrm{P}<0,05)$. Simpulan penelitian ini adalah bahwa pemberian isi rumen kerbau sebagai probiotik dengan level berbeda tidak berpengaruh nyata terhadap nilai KcBK dan KcBO. Nilai TDN pakan meningkat dengan penggunaan probiotik isi rumen kerbau $5 \%$ dibandingkan dengan penggunaan probiotik isi rumen kerbau lebih dari 5\%.
\end{abstract}

Kata kunci : isi rumen kerbau, $K c B K, K c B O$ dan TDN

\section{ABSTRACT}

This research was aimed to examine dry matter digestibility (DMD), organic matter digestibility (OMD) and total digestible nutrients $(T D N)$ in balibul lambs which received complete feed supplemented with different levels of buffalo rumen contents as probiotic. Material used in this study were 16 heads of thin-tailed lamb males aged under 5 months with initial average body weight of $11.52 \pm 0.78 \mathrm{~kg}$. Experimental design used was completely randomized design (CRD) with 4 treatments dan 4 replications. Treatments applied were TO (complete feed without buffalo rumen content), T1 (complete feed with 5\% buffalo rumen contents), T2 (complete feed with $10 \%$ buffalo rumen contents) and T3 (complete feed with $15 \%$ buffalo rumen contents). Parameters observed were DMD, OMD and TDN. Result of the research showed that feeding of complete feed containing different level of buffalo rumen content as probiotic did not significantly affect DMD and OMD in lambs $(P>0.05)$, but significantly affected TDN values in lambs $(P<0.05)$. It was concluded that different level of buffalo rumen contents as probiotics did not significantly affect on DMD and

Pengaruh Suplementasi Probiotik Isi Rumen Kerbau Dengan Level Berbeda Terhadap Nilai Kecernaan dan TDN 
OMD values. TDN value of feed increased with the use of 5\% buffalo rumen contents as probiotics compared to more than $5 \%$ level of buffalo rumen contents as probiotics.

Key words: Buffalo rumen content, DMD, DOM, TDN

\section{PENDAHULUAN}

Domba ekor tipis (DET) dikenal sebagai domba asli Indonesia yang telah banyak dikembangkan di berbagai wilayah di Indonesia. Domba memiliki kelebihan dibanding ternak ruminansia lainnya, yaitu mudah dipelihara, tidak memerlukan tempat luas dan memiliki daya adaptasi yang cukup baik sehingga dapat dijumpai diberbagai lingkungan, baik basah, kering maupun tropis (ekstrim) (Rusdiana dan Praharani, 2015). Karakteristik DET secara khusus membedakan dari yang lain dilihat dari ekornya yang tipis, selain itu tubuhnya tergolong kecil dibandingkan domba lokal lainnya (Sodiq dan Abidin, 2008). Pembesaran domba perlu didukung dengan beberapa faktor seperti lingkungan dan pakan, baik kandungan nutrien dan jumlah pakan yang diberikan serta faktor genetik pada masing-masing individu ternak (Faisal et al., 2017).

Pakan merupakan faktor utama dalam usaha peternakan, pakan yang diberikan pada ternak dapat berupa hijauan dan konsentrat ataupun dalam bentuk pakan komplit. Pakan komplit merupakan jenis pakan ternak yang tersusun dari pakan sumber serat, protein, vitamin dan mineral serta zat aditif yang disusun secara seimbang (Wahjuni dan Bijanti, 2006). Pakan komplit mengandung nutrien yang cukup untuk ternak dalam tingkat fisiologis tertentu (Fachiroh et al., 2012). Pemanfaatan pakan komplit merupakan solusi bagi peternak akan ketersediaan hijauan di musim kemarau, karena penyediaan pakan komplit dapat digunakan dalam jangka panjang (Suwignyo et al., 2016).
Probiotik adalah bahan aditif yang mengandung mikroorganisme hidup sehingga dapat membantu proses pencernaan pakan. Probiotik yang baik mengandung mikroba yang bersifat tidak patogen, aktif di dalam rumen (tidak dorman) dan dapat hidup di saluran pencernaan secara anaerob (Nur, 2017). Bahan yang dapat dikatakan sebagai probiotik mengandung jumlah mikroba berkisar kurang lebih $5 \times 10^{10}$ koloni/g bahan probiotik (Haryanto, 2000). Probiotik dapat diperoleh dari salah satu limbah hasil pemotongan ternak yaitu isi rumen yang menggandung mikroba dan pakan yang belum tercerna seluruhnya. Isi rumen kerbau mengandung bakteri selulolitik $2,4 \times 10^{3} \mathrm{sel} / \mathrm{g}$ bolus dan total bakteri $2,9 \times 10^{10} \mathrm{sel} / \mathrm{g}$ bolus (Aprintasari et al., 2012). Mikroba yang terdapat dalam bolus kerbau yaitu bakteri selulolitik, lipolitik, proteolitik dan amilotilik, fungi, yeast dan protozoa dengan total bakteri yang tinggi (Dewi et al., 2012). Rumen kerbau dewasa terdapat bakteri selulolitik seperti Ruminococcus albus, Bacteroides succinogenes, Butyrivibrio fibrisolvens, Clostridium lochheadii, Clostridium longisporum dan Clostridium spp (Sinha dan Rancanathan, 1983). Penggunaan probiotik sebagai salah satu alternatif untuk mengontrol fermentasi rumen agar lebih efisien dalam penggunaan nutrien pakan dan dapat meningkatkan aktivitas mikroba rumen sehingga dapat meningkatkan kecernaan pakan (Puastuti, 2009).

Kecernaan merupakan nilai ukur proses pencernaan dan penyerapan nutrien pakan di saluran pencernaan berdasarkan jumlah dan kandungan nutrien pakan. 
Kecernaan nutrien pada ternak ruminansia berhubungan dengan jumlah dan aktivitas mikroba di dalam rumen. Faktor yang mempengaruhi kecernaan nutrien pakan meliputi kandungan nutrien, komposisi bahan pakan, bentuk fisik pakan, kondisi fisiologis ternak dan jumlah pakan yang dikonsumsi (Marhaeniyanto dan Susanti, 2011). Kecernaan nutrien dapat dilihat dari kandungan nutrien dari bahan pakan yang terkonsumsi dan feses. Pengukuran nilai kecernaan nutrien dapat dilakukan menggunakan metode total koleksi (Ekawati et al., 2014).

Total digestible nutrients (TDN) merupakan total energi nutrien tercerna oleh ternak yang dapat diperoleh secara biologis dan melalui data analisis proksimat. Nilai TDN dapat diperoleh berdasarkan kecernaan komponen serat, protein, lemak dan karbohidrat dalam pakan (Van Soest, 1994). Faktor-faktor mempengaruhi besar kecilnya nilai TDN adalah kondisi ternak dan lingkungan, jenis kelamin, bobot badan dan komposisi pakan (Khairi et al., 2014). Hal ini menunjukkan bahwa perlu pengkajian lebih lanjut mengenai pengaruh penggunaan isi rumen dengan level berbeda dalam pakan terhadap kecernaan bahan kering (KcBK), bahan organik $(\mathrm{KcBO})$ dan total digestible nutrients (TDN). Penelitian ini bertujuan untuk mengkaji KcBK, KcBO dan TDN pada domba balibul yang mendapat pakan komplit disuplementasi probiotik isi rumen kerbau pada level berbeda.

\section{MATERI DAN METODE}

Penelitian dilaksanakan pada bulan Juli - November 2019 di Kandang Digesti dan Laboratorium Ilmu Nutrisi dan Pakan, Departemen Peternakan, Fakultas Peternakan dan Pertanian, Universitas Diponegoro, Semarang. Materi penelitian yang digunakan adalah domba ekor tipis (DET) jantan berumur di bawah 5 bulan (balibul) dengan bobot badan awal ratarata $11,52 \pm 0,78 \mathrm{~kg}$ sebanyak 16 ekor. Bahan pakan yang digunakan dalam pakan komplit adalah onggok, jagung giling, bekatul, pollard, bungkil kedelai, bungkil kelapa, susu skim, mineral mix dan molases, serta hijauan berupa rumput gajah. Perlakuan yang diterapkan berupa isi rumen kerbau. Kandungan nutrien ransum tertera pada Tabel 1.

Tabel 1.

Kandungan Nutrien Pakan Komplit

\begin{tabular}{lcccc}
\hline \hline Kandungan Nutrien $(\%)$ & T0 & T1 & T2 & T3 \\
\hline Bahan Kering & 70,47 & 74,38 & 74,48 & 77,68 \\
Abu & 8,65 & 9,70 & 10,11 & 11,44 \\
Protein Kasar & 14,58 & 14,50 & 14,54 & 15,39 \\
Serat Kasar & 28,65 & 28,84 & 30,14 & 27,86 \\
Lemak Kasar & 6,02 & 5,71 & 4,73 & 4,90 \\
BETN & 42,10 & 41,26 & 40,50 & 40,42 \\
TDN & 67,10 & 66,96 & 66,56 & 66,08 \\
\hline
\end{tabular}

Sumber: Hasil analisis proksimat di Laboratorium Ilmu Nutrisi dan Pakan Fakultas Peternakan dan Pertanian Universitas Diponegoro (2019)

Rancangan percobaan yang Perlakuan yang diterapkan adalah T0 digunakan dalam penelitian ini adalah (pakan komplit dan tanpa probiotik isi rancangan acak lengkap (RAL) yang rumen kerbau), T1 (pakan komplit dengan terdiri dari 4 perlakuan dengan 4 ulangan. $\quad 5 \%$ isi rumen kerbau), T2 (pakan komplit 
dengan $10 \%$ isi rumen kerbau) dan $\mathrm{T} 3$ (pakan komplit dengan $15 \%$ isi rumen kerbau).

Penelitian dilakukan dengan tahaptahap seperti persiapan, adaptasi, pendahuluan, pengambilan data dan analisis kimiawi. Tahap persiapan yang dilakukan berupa pengadaan bahan pakan, persiapan kandang dan alat, perhitungan populasi mikroba, analisis bahan pakan, formulasi pakan komplit sesuai kebutuhan, pembuatan pakan, serta pengadaan domba. Tahap adaptasi yaitu pengadaptasian domba pada kondisi lingkungan perkandangan dan pakan perlakuan yang diberikan. Tahap pendahuluan dilakukan pengacakan domba sesuai perlakuan yang diberikan dan pemberian pakan perlakuan sebanyak 5\% BK dari bobot badan domba bertujuan untuk mengetahui seberapa banyak ternak dapat mengkonsumsi pakan perlakuan serta air minum. Tahap perlakuan dilakukan pemberian pakan pakan perlakuan sebanyak $5 \% \mathrm{BK}$ dari bobot badan domba dan air minum secara ad libitum. Tahap pengambilan data dilakukan dengan pencatatan jumlah pemberian dan sisa pakan serta penampungan feses, selain itu pengambilan sampel pemberian, sisa dan feses juga dilakukan. Tahap analisis kimiawi melalui analisis proksimat berupa pengujian kadar air, abu, protein kasar, lemak kasar dan serat kasar pada sampel pemberian dan sisa pakan serta feses di laboratorium untuk mengetahui nilai kecernaan nutrien. Parameter yang diamati yaitu KcBK, KcBO dan TDN. Kecernaan dapat dihitung menggunakan rumus Tillman et al. (1991).

$$
\begin{aligned}
& \operatorname{KcBK}(\%)=\frac{\text { BK yang dikonsumsi-BK Feses }}{\text { BK yang dikonsumsi }} \times 100 \% \\
& \operatorname{KcBO}(\%)=\frac{\text { BO yang dikonsumsi-BO Feses }}{\text { BO yang dikonsumsi }} \times 100 \% \\
& \operatorname{TDN}(\%)=\text { PKdd }(\%)+\text { SKdd }(\%)+\text { BETNdd } \\
& \text { PKdd }(\%)=\frac{(\text { KcPK } \times \% \text { PK })}{100} \\
& \operatorname{SKdd~}(\%)=\frac{(\text { KcSK } \times \% \text { SK })}{100} \\
& \text { BETNdd }(\%)=\frac{(\text { KcBETN } \times \% \text { BETN })}{100} \\
& \text { LKdd }(\%) \quad=\frac{(\text { KcLK } \times \% \text { LK })}{100}
\end{aligned}
$$

\section{HASIL PEMBAHASAN}

Tabel 2.

Rata-rata KcBK, KcBO dan TDN Domba Balibul

\begin{tabular}{lcccc}
\hline \multirow{2}{*}{ Parameter } & \multicolumn{4}{c}{ Perlakuan } \\
& T0 & T1 & T2 & T3 \\
\hline KcBK & $62,74 \pm 3,32$ & $65,35 \pm 1,56$ & $64,83 \pm 2,40$ & $62,58 \pm 2,15$ \\
KcBO & $67,42 \pm 2,68$ & $69,56 \pm 1,26$ & $68,95 \pm 2,13$ & $66,82 \pm 2,14$ \\
TDN & $69,42 \pm 2,37^{\text {ab }}$ & $71,79 \pm 1,72^{\text {a }}$ & $67,00 \pm 2,03^{\mathrm{b}}$ & $67,85 \pm 1,06^{\mathrm{b}}$ \\
\hline
\end{tabular}

${ }^{\mathrm{ab}}$ Superskrip yang berbeda pada baris yang sama menunjukkan perbedaan nyata $(\mathrm{P}<0,05)$

Kecernaan Bahan Kering (KcBK)

Rata-rata nilai KcBK pakan masing-masing perlakuan adalah sebesar $62,74 \pm 3,32 \%$ (T0), 65,35 $\pm 1,56 \%$ (T1), $64,83 \pm 2,40 \%$ (T2) dan 62,58 $\pm 2,15 \%$ (T3). Hasil analisis ragam memperlihatkan bahwa perlakuan pakan komplit dengan level probiotik isi rumen kerbau yang berbeda tidak memberikan pengaruh nyata $(\mathrm{P}>0,05)$ terhadap nilai $\mathrm{KcBK}$ pakan pada domba balibul. Pemberian isi rumen dengan level berbeda pada pakan komplit 
menghasilkan nilai KcBK berkisar 62,58 65,35\%. Hasil KcBK lebih tinggi dibandingkan dengan penelitian Winarti et al. (2017) yang menyatakan bahwa nilai KcBK pada domba yang diberi pakan sumber serat dengan penambahan probiotik Bioplus dan $S$. cerevisiae berkisar 41,99 - 55,48\%. Krisnan et al. (2009) menyatakan bahwa domba Priangan yang diberi pakan konsentrat dengan penambahan campuran probiotik dan suplemen katalik 0,5 dan $1,0 \%$ berkisar 58,79-61,06\%.

Nilai KcBK antar perlakuan tidak berbeda nyata $(\mathrm{P}>0,05)$ menunjukkan bahwa pengaruh perlakuan yang diberikan relatif sama sehingga $\mathrm{T} 1$ hanya lebih tinggi secara numerik dibandingkan dengan T0 dan perlakuan yang lain, akan tetapi secara statistik tidak berbeda nyata. Hal ini dapat diartikan bahwa penggunaan probiotik isi rumen kerbau pada ransum yang diberikan belum berpengaruh terhadap KcBK terjadi karena kandungan PK dan TDN yang relatif sama pada setiap perlakuan (Tabel 2). Marhaeniyanto dan Susanti (2011) menyatakan bahwa jumlah pakan yang dikonsumsi, kandungan nutrien dan komposisi bahan pakan dapat mempengaruhi tingkat kecernaan pada ternak. Kandungan SK yang hampir sama pada setiap perlakuan (Tabel 2) juga dapat mempengaruhi KcBK. Ambari et al. (2018) menyatakan bahwa kandungan serat (NDF) yang berbeda dapat mempengaruhi tingkat kecernaan pakan. Konsumsi BK yang relatif sama juga mempengaruhi hasil KcBKnya. Tillman et al. (1991) menyatakan bahwa daya cerna sangat berhubungan dengan konsumsi, karena saat daya cerna meningkat akan diikuti peningkatan konsumsi. Faktor lain yang mempengaruhi $\mathrm{KcBK}$ ternak antara lain laju pakan dalam saluran pencernaan dan kondisi fisiologis. Anggorodi (1994) menyatakan bahwa kecernaan pada ternak dipengaruhi oleh bentuk fisik bahan pakan, komposisi ransum, suhu dan laju perjalanan melalui alat pencernaan.

\section{Kecernaan Bahan Organik (KcBO)}

Rata-rata nilai $\mathrm{KcBO}$ setiap perlakuan adalah 67,42 $\pm 2,68 \%$ (T0), $69,56 \pm 1,26 \%$ (T1), 68,95 $\pm 2,13 \%$ (T2) dan 66,82 $\pm 2,14 \%$ (T3). Hasil analisis ragam memperlihatkan bahwa perlakuan pakan komplit dengan level probiotik isi rumen kerbau yang berbeda tidak memberikan pengaruh nyata $(\mathrm{P}>0,05)$ terhadap nilai $\mathrm{KcBO}$ pakan pada domba balibul. Penggunaan isi rumen dengan level berbeda pada pakan komplit menghasilkan nilai $\mathrm{KcBO}$ sebesar 66,82 69,56\%. Hasil tersebut lebih rendah dibandingkan hasil penelitian Gultom et al. (2014) bahwa domba lokal yang diberi jerami padi fermentasi dengan probiotik Starbio memperoleh nilai KcBO sebesar 57,06 - 59,85\%. Wulandari et al. (2014) menyatakan bahwa domba yang diberi pakan komplit berbasis pod kakao memiliki tingkat $\mathrm{KcBO}$ berkisar 52,4 $55,6 \%$.

Nilai KcBO antar perlakuan tidak berbeda nyata $(\mathrm{P}>0,05)$ menunjukkan bahwa pengaruh perlakuan yang diberikan relatif sama sehingga $\mathrm{T} 1$ hanya lebih tinggi secara numerik dibandingkan dengan T0 dan perlakuan yang lain, akan tetapi secara statistik tidak berbeda nyata. Hal ini dapat diartikan bahwa penggunaan probiotik isi rumen kerbau pada ransum yang diberikan belum berpengaruh terhadap KcBO karena kandungan PK dan TDN serta BO yang relatif sama (Tabel 2). Nilai KcBO dapat meningkat apabila nilai KcBK juga mengalami peningkatan. Andayani (2010) menyatakan bahwa $\mathrm{KcBO}$ akan sejalan dengan KcBK, apabila $\mathrm{KcBK}$ tinggi maka $\mathrm{KcBO}$ juga akan tinggi karena BO merupakan bagian dari BK. Nilai KcBO lebih tinggi dibandingkan dengan $\mathrm{KcBK}$ dapat terjadi karena dalam BK masih mengandung abu di dalamnya. 
Fathul dan Wajizah (2010) menyatakan bahwa bahan tanpa kandungan abu akan lebih mudah dicerna sehingga keberadaan abu dapat memperlambat atau menghambat KcBK.

\section{Total Digestible Nutrients (TDN)}

Rata-rata nilai TDN pakan diperoleh data seperti yang disajikan Tabel 3. Rerata nilai TDN pakan setiap perlakuan adalah sebesar $69,38 \pm 2,37 \%$ (T0), 71,37 $\pm 1,72 \%$ (T1), 66,58 $\pm 2,03 \%$ (T2) dan 67,51 $\pm 1,06 \%$ (T3). Hasil analisis ragam memperlihatkan bahwa perlakuan pakan komplit dengan level probiotik isi rumen kerbau yang berbeda memberikan pengaruh nyata $(\mathrm{P}<0,05)$ terhadap nilai TDN pakan pada domba balibul. Hasil uji lanjut Duncan terhadap TDN menunjukkan bahwa nilai TDN tertinggi terjadi pada perlakuan T1 dengan penggunaan isi rumen kerbau 5\%. Hal tersebut dapat diartikan bahwa penggunaan isi rumen kerbau 5\% dari pakan komplit yang diberikan mampu memberikan pengaruh pada total energi yang tercerna menjadi lebih baik. Nilai TDN pada perlakuan T1 secara statistik tidak berbeda nyata dengan perlakuan T0, tetapi secara numerik nilai TDN pada perlakuan T1 lebih tinggi dibandingkan dengan T0. Penggunaan isi rumen kerbau sebesar 10 dan 15\% (T2 dan T3) nyata $(\mathrm{P}<0,05)$ menurunkan nilai TDN dibandingkan perlakuan T0 dan T1.

Penggunaan isi rumen dengan level berbeda pada pakan komplit menghasilkan nilai TDN sebesar $67,00-71,79 \%$. Hasil tersebut lebih tinggi dibandingkan dengan hasil penelitian Saleem et al. (2017) bahwa pemberian campuran dua jenis bakteri Pediococcus sebesar 0,5 dan 1,0\% pada domba sebelum dan setelah sapih berkisar 57,95 - 64,28\%. Hassan dan Mohammed (2014) menyatakan bahwa TDN domba Awassi yang diberi penambahan $S$. cerevisiae pada hijauan dan konsentrat dengan rasio berbeda berkisar $60-65 \%$. Bhatta et al. (2006) menyatakan bahwa pemberian pakan komplit dapat meningkatkan nilai TDN karena dapat mengurangi pengeluaran energi selama proses pencernaan disamping juga meningkatkan konsumsi pakan.

Hasil analisis ragam nilai TDN pada domba meningkat terjadi karena kandungan nutrien seperti LK yang relatif tinggi (Tabel 2) yang mana lemak memiliki nilai energi 2,25 kali lebih tinggi dibandingkan komponen lain sehingga dapat meningkatkan nilai TDN. Tillman et al. (1991) menyatakan bahwa nilai TDN diperoleh berdasarkan nilai PK-dapat dicerna (PKdd), SK-dapat dicerna (SKdd), BETN-dapat dicerna (BETNdd) dan 2,25 LK-dapat dicerna (LKdd). Parakkasi (1999) menyatakan bahwa kandungan lemak dalam ransum dapat meningkatkan tingkat konsumsi pada ternak. Lubis (1992) menyatakan bahwa kandungan nutrien pada bahan pakan yang dapat dicerna tinggi pada umumnya tinggi pula nilai nutriennya.

Penggunaan isi rumen kerbau sebagai probiotik yang semakin meningkat menyebabkan populasi mikroba di dalam rumen meningkat sehingga dapat meningkatkan kecernaan serat. Van Soest (1994) menyatakan bahwa nilai TDN berhubungan dengan kecernaan nutrien pakan seperti serat, lemak, protein dan karbohidrat. Riswandi et al. (2015) menyatakan bahwa pemberian probiotik Bioplus di dalam pakan menyebabkan aktivitas mikroba di dalam rumen meningkat sehingga kemampuan mencerna nutrien akan meningkat.

Data pendukung pertambahan bobot badan harian (PBBH) domba balibul sebesar 82,$95 ; 129,91 ; 121,96$ dan 91,52 g/ekor/hari pada perlakuan T0, T1, T2 dan T3. Data tersebut memperlihatkan bahwa penambahan probiotik isi rumen kerbau 
dapat meningkatkan PBBH domba balibul. Energi (TDN) yang dikonsumsi oleh ternak ruminansia pada gilirannya akan digunakan untuk pembentukan daging. Energi merupakan faktor esensial bagi semua makhluk hidup (termasuk ternak) untuk menopang kehidupan (Jayanegara $e t$ al., 2019). Determinasi energi untuk ternak dilakukan melalui pakan dan secara substansial menentukan tingkat produksi ternak untuk menyediakan daging dan susu untuk konsumsi manusia. Nutrien utama yang menyumbang energi adalah karbohidrat (baik karbohidrat struktural maupun non-struktural), lemak dan protein (Hall dan Eastridge, 2014). Energi akan mempengaruhi pembentukan asam-asam lemak atsiri di dalam rumen yang merupakan sumber energi utama bagi ternak ruminansia (Haryanto, 2013).

\section{SIMPULAN}

Berdasarkan hasil penelitian dapat disimpulkan bahwa pemberian isi rumen kerbau sebagai probiotik dengan level berbeda tidak meningkatkan nilai $\mathrm{KcBK}$ dan KcBO. Nilai TDN pakan meningkat dengan penggunaan probiotik isi rumen kerbau $5 \%$ dibandingkan dengan penggunaan probiotik isi rumen kerbau lebih dari 5\%. Penggunaan isi rumen kerbau sebagai probiotik dapat meningkatkan PBBH domba balibul. 


\section{DAFTAR PUSTAKA}

Ambari, M. Z., Surono dan Sutrisno. 2018. Pengaruh pakan komplit dengan level NDF berbeda yang mengandung probiotik isi rumen kerbau pada domba terhadap nilai kecernaan dan TDN. Prosiding Simposium Nasional "Inovasi Teknologi Peternakann Menyongsong Era Industri 4.0". Yogyakarta, 5 November 2018. Universitas Gadjah Mada, Yogyakarta. Hal. 40 $-44$.

Andayani, J. 2010. Evaluasi kecernaan in vitro bahan kering, bahan organik dan protein kasar penggunaan kulit buah jagung amoniasi dalam ransum ternak sapi. Jurnal Ilmiah Ilmu-ilmu Peternakan. 13 (5): 252 -259 .

Anggorodi, R. 1994. Ilmu Makanan Ternak Umum. PT Gramedia, Jakarta.

Aprintasari, R., C. I. Sutrisno dan B. I. M. Tampoeboelon.2012.Uji total fungi dan organoleptik pada jerami padi dan jerami jagung yang difermentasi dengan isi rumen kerbau. Anim. Agric. J. 1 (2): 311 321.

Bhatta, R., V. Kumar, M. Sridhar dan K. Singh. 2006. Energy expenditure in crossbred cattle fed paddy straw of different form. Asian-Aust. Anim. Sci. J. $19: 1755-1760$.

Dewi, N. K., S. Mukodiningsih dan C. I. Sutrisno. 2012. Pengaruh fermentasi kombinasi jerami padi dan jerami jagung dengan aras isi rumen kerbau terhadap kecernaan bahan kering dan bahan organik secara in vitro. Anim. Agric. J. 1 (2): $134-140$.

Ekawati, E., A. Muktiani dan Sunarso. 2014. Efisiensi dan kecernaan ransum domba yang diberi silase ransum komplit enceng gondok ditambah starter Lactobacillus plantarum. Agripet. 14 (2): 107 114.

Fachiroh, L., B. W. H. E. Prasetiyono dan A. Subrata. 2012. Kadar protein dan urea darah kambing perah Peranakan Etawa yang diberi wafer pakan komplit berbasis limbah agroindustri dengan suplementasi protein terproteksi. Anim. Agric. J. 1 (1): 443 - 451.

Faisal, F., A. Rochana dan A. K. Kurnia. 2017. Kajian kandungan kimia darah dan pertambahan bobot badan domba garut betina lepas sapih dengan imbangan protein dan energi yang berbeda. Jurnal Ilmu Ternak. 17 (2): 94 - 98.

Fathul, F. dan S. Wajizah. 2010. Penambahan mikromineral Mn dan $\mathrm{Cu}$ dalam ransum terhadap aktivitas biofermentasi rumen domba secara in vitro. Jurnal Ilmu Ternak dan Veteriner. 15 (1): 9-15. Gultom, G. P., T. H. Wahyuni dan N. D. Hanafi. Kecernaan jerami padi fermentasi dengan probiotik Starbio pada domba jantan lokal. Jurnal Peternakan Integratif. 1 (2): $146-154$.

Hall, M.B. dan M.L. Eastridge. 2014. Carbohydrate and fat: Considerations for energy and more. Professional Animal Scientist. 30: 140-149.

Haryanto, B. 2000. Penggunaan probiotik dalam pakan untuk meningkatkan kulitas karkas dan daging domba. Jurnal Ilmu Ternak dan Veteriner. 5 (4): $1-5$.

Haryanto, B. 2013. Perkembangan penelitian nutrisi ruminansia. Wartazoa. 22 (4): 169 - 177.

Hassan, S. A. dan S. F. Mohammed. 2014. Effects of Saccharomyces cerevisiae supplementation on growth rate and nutrient 
digestibility in Awassi lambs fed diets with different roughage to concentrate ratios. Biochem. Biotechnol. Res. 2 (3): 37 - 43.

Jayanegara, A., M. Ridla, Nahrowi dan E.B. Laconi. 2019. Estimation and validation of total digestible nutrient values of forage and concentrate feedstuffs. IOP Conf. Series: Mater. Sci. Eng. doi:10.1088/1757899X/546/4/042016.

Khairi, F., A. Muktiani dan Y. S. Ondho. 2014. Pengaruh suplementasi vitamin E, mineral Selenium dan Zink terhadap konsumsi nutrien, produksi dan kualitas semen Sapi Simental. Agripet. 14 (1): 6- 16.

Krisnan, R., B. Haryanto dan K. G. Wiryawan. 2009. Pengaruh kombinasi penggunaan probiotik mikroba rumen dengan suplemen katalitik dalam pakan terhadap kecernaan dan karakteristik rumen domba. Jurnal Ilmu Ternak dan Veteriner. 14 (4): $262-269$.

Lubis, D. A. 1992. Ilmu Makanan Ternak. Cetakan Ulang. PT Pembangunan, Jakarta.

Marhaeniyanto, E. dan S. Susanti. 2011. Strategi suplementasi leguminosa untuk meningkatkan penampilan domba. Buana Sains. 11 (1): 7-16.

Nur, F. 2017. Potensi Bakteri Asam Laktat yang Diisolasi dari Dangke sebagai Kandidat Probiotik dalam Menghambat Bakteri Patogen. Program Pasca Sarjana Universitas Hasanuddin, Makassar (Disertasi).

Parakkasi, A. 1999. Ilmu Nutrisi dan Makanan Ternak Ruminansia. UI Press, Jakarta.

Puastuti, W. 2009. Manipulasi bioproses dalam rumen untuk meningkatkan penggunaan pakan berserat. Wartazoa. 9 (4): 180 - 190.
Riswandi, Muhakka dan M. Lehan. 2015. Evaluasi nilai kecernaan secara in vitro ransum ternak sapi Bali yang disuplementasi dengan probiotik Bioplus. Jurnal Peternakan Sriwijaya. 4 (1): 35 - 46.

Rusdiana, S. dan L. Praharani. 2015. Peningkatan usaha ternak domba melalui diversifikasi tanaman pangan: ekonomi pendapatan pertanian. Agriekonomika. 4 (1): $80-96$.

Saleem, A. M., A. I. Zanouny dan A. M. Singer 2017 . Growth performance, nutrients digestibility, and blood metabolites of lambs fed diets supplemented with probiotics during pre- and post weaning period. Asian-Australas. J. Anim. Sci. 30 (4): $523-530$.

Sinha, R. N. dan B. Rancanathan. 1983. Cellulolytic bacteria in buffalo rumen. J. Appl. Bacteriol. 54: 1-6.

Sodiq, I. A. dan I. Z. Abidin. 2008. Sukses Menggemukan Domba. Penebar Swadaya, Jakarta.

Suwignyo, B., A. Agus, R. Utomo, N. Umami, B. Suhartanto dan C. Wulandari. 2016. Penggunaan fermentasi pakan komplet berbasis hijauan pakan dan jerami untuk pakan ruminansia. Indonesian Journal of Community Engagement. 1 (2): 255 - 263.

Tillman, A. D., S. Rekshohadiprodjo, S. Prawirokusumo, H. Hartadi dan S. Lebdosoekojo. $\quad 1991 . \quad$ Ilmu Makanan Ternak Dasar. Edisi Keempat. Gajah Mada University Press, Yogyakarta.

Van Soest, P. J. 1994. Nutritional Ecology of the Ruminant. $2^{\text {nd }}$ Ed. Cornell University Press, Ithaca.

Wahjuni, R. S. dan R. Bijanti. 2006. Uji efek samping formula pakan komplit terhadap fungsi hati dan ginjal pedet sapi Friesian Holstein. 
Media Kedokteran Hewan. 22 (3): $174-178$.

Winarti, E., A. Widyastuti dan K. Triwidyastuti. 2017. Pengaruh penggunaan Bioplus dan rater dalam pakan kaya serat terhadap kinerja domba muda. Jurnal Pengkajian Pengembangan Teknologi Pertanian. 20 (3): 221 230.

Wulandari, S., A. Agus, M. Soejono, M. W. Cahyanto dan R. Utomo. 2014. Performan produksi domba yang diberi compleet feed fermentasi berbasis pod kakao serta nilai nutrien tercernanya secara in vivo. Buletin Peternakan. 38 (1): 42 50 . 